\title{
FIRST SINGLE-PORT LAPAROSCOPIC PANCREATECTOMY IN BRAZIL
}

\author{
Marcel Autran Cesar MACHADO, Rodrigo Cañada Trofo SURJAN and \\ Fábio Ferrari MAKDISSI
}

\begin{abstract}
Context - Pancreatic surgery is an extremely challenging field, and the management of pancreatic diseases continues to evolve. In the past decade, minimal access surgery is moving towards minimizing the surgical trauma by reducing numbers and size of the port. In the last few years, a novel technique with a single-incision laparoscopic approach has been described for several laparoscopic procedures. Objectives - We present a single-port laparoscopic spleen-preserving distal pancreatectomy. To our knowledge, this is the first single-port pancreatic resection in Brazil and Latin America. Methods - A 33-year-old woman with neuroendocrine tumor underwent spleen-preserving distal pancreatectomy via single-port approach. A single-incision advanced access platform with gelatin cap, self-retaining sleeve and wound protector was used. Results - Operative time was 174 minutes. Blood loss was minimal, and the patient did not receive a transfusion. The recovery was uneventful, and the patient was discharged on postoperative day 4 . Conclusions - Single-port laparoscopic spleen-preserving distal pancreatectomy is feasible and can be safely performed in specialized centers by skilled laparoscopic surgeons.
\end{abstract}

HEADINGS - Pancreatectomy. Laparoscopy.

\section{INTRODUCTION}

Pancreatic surgery is an extremely challenging field, and the management of pancreatic diseases continues to evolve. In the past decade, minimal access surgery is moving towards minimizing the surgical trauma by reducing numbers and size of the port. In the last few years, a novel technique with a singleincision laparoscopic approach has been described ${ }^{(2)}$. This technique is especially used in young female patients due to the splendid cosmetic results.

In Brazil, this technique has been mainly used for laparoscopic cholecystectomy ${ }^{(11)}$. This report will present our initial experience with single-port technique through a small transumbilical incision for laparoscopic pancreas resection. We present a single-port laparoscopic spleen-preserving distal pancreatectomy.

To our knowledge, this is the first single-port pancreatic resection in Brazil and Latin America and the first case of neuroendocrine tumor treated by this method, so far, in the English literature.

\section{METHODS}

A 33-year-old woman from a family with multiple endocrine neoplasia type 1 (MEN1) was found to have a solid tumor in the body of the pancreas during follow-up. CT scan disclosed a $1.8 \mathrm{~cm}$ tumor compatible with neuroendocrine tumor. Patient was nulliparous and presented no other medical or surgical relevant past history. Patient was referred for surgical treatment. The patient was informed about the details of the surgical procedure, and informed consent was obtained. She subsequently underwent spleen-preserving distal pancreatectomy via singleport approach.

\section{Surgical Technique}

The patient was under general anesthesia and placed in a supine and reverse Trendelenburg position with surgeon between patient's legs. First assistant was on the right side of the patient with the monitor placed on the patient's cranial side. With the patient under general anesthesia, a completely transumbilical $3 \mathrm{~cm}$ skin incision was performed (Figure 1A). A single-incision advanced access platform with gelatin cap, self-retaining sleeve and wound protector (GelPoint, Applied Med. R. S. Margarita, CA, USA) was introduced through this incision. (Figure 1B). Three $5-10 \mathrm{~mm}$ working ports were introduced through the single-port device (Figure 1C). Due to the gel cap and sleeves, no articulated instruments were necessary. $\mathrm{CO}_{2}$ pneumoperitoneum is established at $12 \mathrm{~mm} \mathrm{Hg}$. A rigid 30 degree $10 \mathrm{~mm}$ laparoscope was introduced. The single port was able to accommodate at the same time three instruments with no triangulation prejudice: a $10 \mathrm{~mm}$ laparoscope, a $12 \mathrm{~mm}$ flexible stapler and a $5 \mathrm{~mm}$ instrument such as harmonic scalpel, grasper, scissor or dissector. 
FIGURE 1. Single port platform set up

A. Opening at the level of umbilicus and insertion of the self-retained sleeve and wound protector

B. Gelatin cap with three working ports are attached to the platform

C. Advanced platform for single port procedure is installed. A 30 degree $10 \mathrm{~mm}$ high definition laparoscope is used together with harmonic scalpel and standard grasper.

D. Intraoperative ultrasound is performed through single port. Laparoscope is the same. Note that there is no need for the use of a $5 \mathrm{~mm}$ laparoscope or flexible instruments.

E. Intraoperative ultrasound shows the pancreatic tumor.

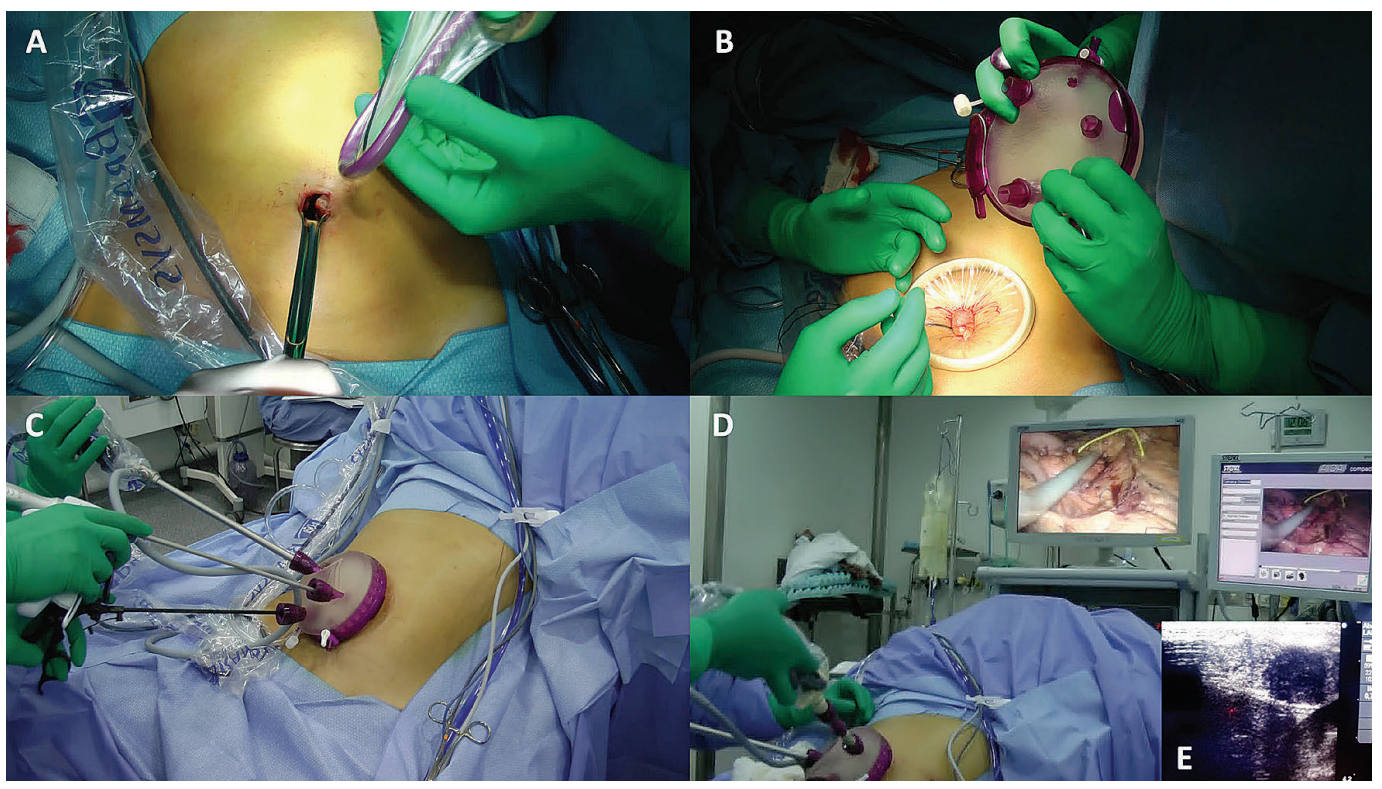

Operation began with access to the lesser sac by opening the omentum along the greater curvature of the stomach using harmonic scalpel (Ultracision, Ethicon Endo Surgery, Cincinnati, $\mathrm{OH})$. After that, intraoperative ultrasound (SonoSite, Inc., Bothell, WA, USA) was used to ascertain tumor location and its relation with splenic vessels (Figure $1 \mathrm{D}, \mathrm{E})$. Splenic artery and vein were not involved by the tumor and we decided to preserve the spleen (Figure 2A). Pancreas inferior border was opened and a tunnel between pancreas and splenic vein was created about $1 \mathrm{~cm}$ away

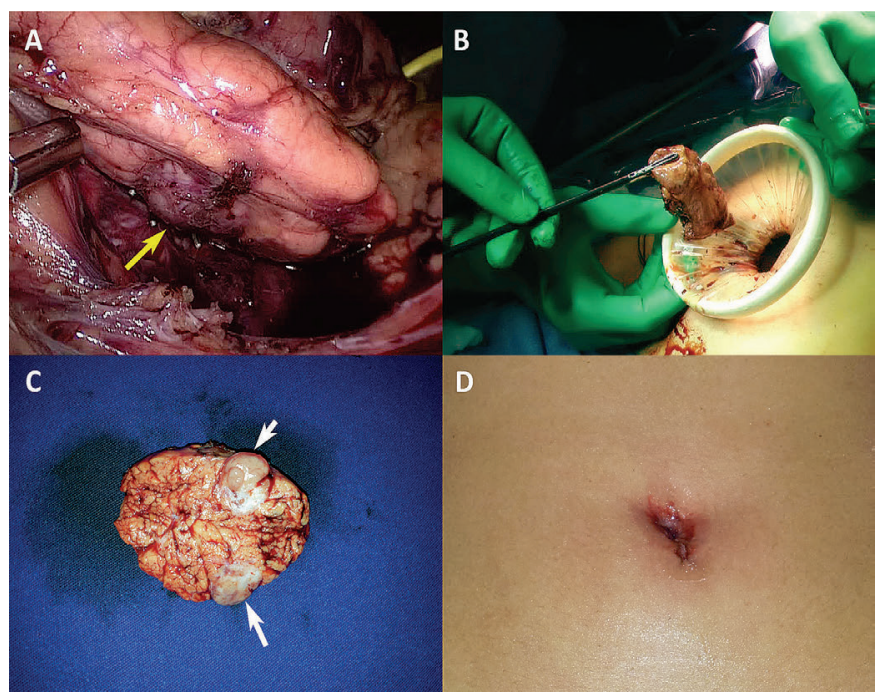

FIGURE 2. Single-port spleen-preserving laparoscopic distal pancreatectomy

A. Intraoperative view of spleen-preserving laparoscopic distal pancreatectomy. Tumor is shown (arrow).

B. Surgical specimen is retrieved through the single incision.

C. Macroscopic view of the surgical specimen. Tumor is shown (arrows).

D. Final view of umbilical wound. from the tumor location. Splenic artery was dissected and encircled. Pancreas is then divided with flexible vascular stapler. Small venous and arterial branches from the pancreas were clipped or divided with harmonic scalpel. Left pancreatectomy was completed. Surgical specimen was removed through the single-port (Figures 2B, C). Pancreas raw surface was checked for bleeding and hemostatic tissue was inserted in the dissected area. Closed suction drain was placed near pancreatic stump Umbilical incision is then closed (Figure 2D).

\section{RESULTS}

Operative time was 174 minutes. Blood loss was minimal, and the patient did not receive a transfusion. The recovery was uneventful, and the patient was discharged on postoperative day 4 . There was no pancreatic leakage, and the drain was removed on postoperative day 7 .

\section{DISCUSSION}

Laparoscopy has become a less invasive alternative to pancreatic surgery, and preoperative and intraoperative imaging advances resulted in better anatomic evaluation and thus better surgical planning.

Laparoscopic pancreatic surgery has experienced significant development in the last few years. Our experience with laparoscopic pancreatic resections began in 2001 with distal pancreatectomy ${ }^{(8)}$. Similarly as occurred with other authors, improvement of our expertise in advanced laparoscopic surgery has allowed us to perform more complex operations such as central pancreatectomies, pancreatoduodenectomy and resection of uncinate process ${ }^{(,, 11)}$. However, only laparoscopic distal pancreatectomy is considered a gold standard. This is mainly due to the standardization of the technique. Based on the available data, laparoscopic distal pancreatectomy have 
adequate safety profiles, equivalent or better perioperative outcomes, and noninferior oncologic outcomes ${ }^{(4-6,14)}$.

Single-incision laparoscopic procedure is less invasive than standard multiport laparoscopy but may have unique difficulties for the laparoscopic surgeon. First, retraction is significantly limited. To overcome this problem some surgeons use stay sutures with straight needles to improve retraction ${ }^{(1,3,13)}$. Another issue is the triangulation. The introduction of a camera and several instruments parallel to each other may result in decreased range of motion and collision of instruments. The single-incision platform used in our case may resolve some of these problems because it allows the use of standard instruments with no loss of triangulation due to the presence of self-retaining sleeves which maximizes internal working diameter. We were able to use a high definition $10 \mathrm{~mm}$ laparoscope during all steps of the operation. Even during introduction of an $11 \mathrm{~mm}$ intraoperative ultrasound probe or a $12 \mathrm{~mm}$ flexible stapler, there was no need for a $5 \mathrm{~mm}$ laparoscope replacing the main laparoscope. In our case stay sutures were not necessary.

In the English literature, to the best of our knowledge, there are only four papers with only five cases of single-port pancreas resection $^{(1,3,7,13)}$. The main reason is that the majority of systems available for single site laparoscopic surgery need special articulating instruments, use of small laparoscopes with poor triangulation. Therefore, more complex surgeries such as pancreatic resection are rarely performed. We have tried some systems for laparoscopic cholecystectomies and we had difficulties in triangulation, exposure and retraction and did not find any advantage over conventional laparoscopy. We believe that this new system may offer a better platform for single-incision surgery reducing learning curve for skill acquisition ${ }^{(10)}$. Our initial experience with single port distal pancreatectomy showed no exposure or triangulation difficulties and operative time was not superior to our other laparoscopic cases.

Although several issues such as costs and learning curve of this technique remain to be studied, the cosmetic benefits of single-incision approach are obvious. In conclusion, single-port laparoscopic spleen-preserving distal pancreatectomy is feasible and can be safely performed in specialized centers by skilled laparoscopic surgeons.

Machado MAC, Surjan RCT, Makdissi FF. Pancreatectomia laparoscópica com portal único. Relato de experiência pioneira no Brasil. Arq Gastroenterol. 2013,50(4):310-2.

RESUMO - Contexto - O tratamento cirúrgico das doenças pancreáticas apresentou uma grande evolução nos últimos anos. A cirurgia minimamente invasiva evoluiu e hoje produz menor trauma graças à utilização da videolaparoscopia com redução do número e tamanho dos trocartes. Recentemente uma nova técnica com uso de portal único foi descrita para diversos procedimentos cirúrgicos. Objetivos - O objetivo deste trabalho é apresentar o primeiro caso que se tem notícia de pancreatectomia laparoscópica com portal único do Brasil e da América Latina. Trata-se de uma pancreatectomia distal laparoscópica com preservação de baço usando esta técnica. Métodos - Paciente de 33 anos de idade, sexo feminino, portadora de tumor neuroendócrino de pâncreas, submetida à pancreatectomia distal com preservação do baço e vasos esplênicos com portal único. Resultados - O procedimento durou 174 minutos. A perda sanguinea estimada foi mínima e a paciente não necessitou de transfusão. Paciente evoluiu bem, sem intercorrências e recebeu alta hospitalar no quarto dia de pós operatório. Conclusão - Pancreatectomia distal com preservação do baço e vasos esplênicos com portal único é procedimento seguro desde que realizado em centros especializados e por equipes com experiência em cirurgia pancreática e laparoscopia avançada.

DESCRITORES - Pancreatectomia. Laparoscopia.

\section{REFERENCES}

1. Barbaros U, Sümer A, Demirel T, Karakullukçu N, Batman B, Içscan Y, Sarıçam G, Serin K, Loh WL, Dinççağ A, Mercan S. Single incision laparoscopic pancreas resection for pancreatic metastasis of renal cell carcinoma. JSLS. 2010;14:566-70

2. Canes D, Desai MM, Aron M, Haber GP, Goel RK, Stein RJ, Kaouk JH, Gill IS. Transumbilical single-port surgery: evolution and current status. Eur Urol. 2008;54:1020-9

3. Chang SK, Lomanto D, Mayasari M. Single-port laparoscopic spleen preserving distal pancreatectomy. Minim Invasive Surg. 2012;2012:197429.

4. Fernández-Cruz L, Cosa R, Blanco L, Levi S, López-Boado MA, Navarro S. Curative laparoscopic resection for pancreatic neoplasms: a critical analysis from a single institution. J Gastrointest Surg. 2007;11:1607-21

5. Fisher SB, Kooby DA. Laparoscopic pancreatectomy for malignancy. J Surg Oncol. 2013;107:39-50.

6. Kneuertz PJ, Patel SH, Chu CK, Fisher SB, Maithel SK, Sarmiento JM, Weber SM, Staley CA, Kooby DA. Laparoscopic distal pancreatectomy: trends and lessons learned through an 11-year experience. J Am Coll Surg. 2012;215:167-76.

7. Kuroki T, Adachi T, Okamoto T, Kanematsu T. Single-incision laparoscopic distal pancreatectomy. Hepatogastroenterology. 2011;58:1022-4.
8. Machado MA, Canedo LF, Herman P, Montagnini AL, Sallum RA, Machado MC. Laparoscopic distal pancreatectomy for pancreatic cystadenomas. Arq Gastroenterol 2005;42:157-160.

9. Machado MA, Makdissi FF, Surjan RC, Machado MC. Laparoscopic pylorus-preserving pancreatoduodenectomy with double jejunal loop reconstruction: an old trick for a new dog. J Laparoendosc Adv Surg Tech A. 2013;23:146-149.

10. Machado MA, Surjan RC, Makdissi FF. Hepatectomia laparoscópica com portal único: Experiência pioneira no Brasil. Arq Bras Cir Dig 2013;26:144-146.

11. Machado MAC, Surjan RCT, Goldman SM, Ardeugh JC, Makdissi FF. Laparoscopic pancreatic resection. From Enucleation to pancreatoduodenectomy. Arq Gastroenterol. 2013; 50:214-8.

12. Madureira FA, Manso JE, Madureira Fo D, Iglesias AC. Randomized clinical study for assessment of incision characteristics and pain associated with LESS versus laparoscopic cholecystectomy. Surg Endosc. 2013;27:1009-15.

13. Misawa T, Ito R, Futagawa Y, Fujiwara Y, Kitamura H, Tsutsui N, Shiba H, Wakiyama S, Ishida Y, Yanaga K. Single-incision laparoscopic distal pancreatectomy with or without splenic preservation: how we do it. Asian J Endosc Surg. 2012;5:195-9.

14. Pericleous S, Middleton N, McKay SC, Bowers KA, Hutchins RR. Systematic review and meta-analysis of case-matched studies comparing open and laparoscopic distal pancreatectomy: is it a safe procedure? Pancreas. 2012;41:993-1000. 